\title{
Genetic Diversity of Ascochyta rabiei in Canada
}

\author{
G. Chongo, B. D. Gossen, L. Buchwaldt, T. Adhikari, and S. R. Rimmer, Agriculture and Agri-Food Canada \\ Research Centre, Saskatoon, SK S7N 0X2, Canada
}

\begin{abstract}
Chongo, G., Gossen, B. D., Buchwaldt, L., Adhikari, T., and Rimmer, S. R. 2004. Genetic diversity of Ascochyta rabiei in Canada. Plant Dis. 88:4-10.

Assessment of variability of Ascochyta rabiei (teleomorph: Didymella rabiei) was based on virulence tests of 40 isolates and on random amplified polymorphic DNA (RAPD) analysis of 39 isolates from Canada. In addition, isolates of $A$. rabiei from other countries were assessed in the virulence (18 isolates) and RAPD (20 isolates) analyses. Seven isolates of A. lentis (teleomorph: Didymella lentis) and two of A. pinodes (teleomorph: Mycosphaerella pinodes) also were included in the RAPD analysis. Significant line-isolate interactions in the virulence tests indicated that certain isolates were virulent only on certain lines. Canadian isolates were grouped into 14 pathotypes using eight chickpea differentials. These groupings also encompassed 17 of the 18 isolates from other countries. RAPD analysis of all 68 isolates using 8 primers produced 112 fragments, of which $96 \%$ were polymorphic. Similarities among A. rabiei isolates from Canada ranged from 20 to $100 \%$. In the RAPD dendrogram, all five A. rabiei isolates from Australia, three of six from Syria, three of five from the United States, and one of two from India clustered within the major groups of Canadian isolates. There was a weak association between RAPD and pathotype groups. A. rabiei was $45 \%$ similar to A. lentis and only $14 \%$ similar to $A$. pinodes. The levels of DNA variability and virulence among isolates show that the population of A. rabiei in Canada is highly diverse.
\end{abstract}

Additional keywords: Ascochyta blight, Cicer arietinum, resistance

Ascochyta blight, caused by Ascochyta rabiei (Pass) Labrousse (teleomorph, Didymella rabiei (Kovachevski) v. Arx.), is the most important constraint to chickpea (Cicer arietinum L.) production in the northern Great Plains, and often results in high yield losses $(2,4)$. The primary sources of inoculum are infested seed and stubble, but airborne ascospores play an important role in dispersal of the pathogen $(1,9,16,24,25)$.

A. rabiei is a heterothallic fungus that requires two compatible mating types to

Corresponding author: G. Chongo

E-mail: godfrey.chongo@bayercropscience.com

This study was partially funded by the CanadaSaskatchewan Agri-Food Innovation Fund.

Present address of G. Chongo: Bayer CropScience, Site 600, Box 117, R.R.\#6, Saskatoon, SK S7K 3J9, Canada.

Present address of T. Adhikari: Crop Production and Pest Control Research, United States Department of Agriculture-Agricultural Research Service, Department of Botany and Plant Pathology, 915 W. State Street, Purdue University, West Lafayette, IN 47907-2054.

Accepted for publication 17 August 2003.

Publication no. D-2003-1030-01R

(C) 2004 The American Phytopathological Society produce the sexual stage (29). Both mating types are present on the Canadian prairies and the teleomorph has been observed in the field $(1,8)$. The presence of sexual recombination in this fungal population is expected to contribute to population diversity. Genotypic variation in $A$. rabiei has been reported from many parts of the world, including India (27), Pakistan (19), Syria and Lebanon (20), the United States (7), and Italy (18).

Studies on population diversity of $A$. rabiei are one step toward understanding the pathogen population. Molecular techniques have been used in several studies to investigate genetic diversity in $\mathrm{A}$. $\mathrm{ra}$ biei, to examine the relationship between molecular markers and pathotypes, and to examine phylogenetic relationships $(5,11,12,15,23,26,28)$. No clear correlations have been reported between markers and pathotype groups $(5,15)$. In one study, specific DNA fragments were associated with geographic origin of the isolates (26).

The objectives of this study were to (i) assess genotypic diversity among isolates of A. rabiei from the northern Great Plains using virulence tests and random amplified polymorphic DNA (RAPD) markers and (ii) compare this diversity with that of a group of isolates from other regions.

\section{MATERIALS AND METHODS}

Virulence study. In a preliminary test, 62 chickpea lines or cultivars were assessed for their reaction to three virulent isolates of $A$. rabiei from commercial fields in Saskatchewan, Canada. Of the 62 chickpea lines, 29 kabuli lines were obtained from the International Center for Agricultural Research in the Dry Areas (ICARDA) in Syria, 20 desi lines from the International Crops Research Institute for the Semi-Arid Tropics (ICRISAT) in India, and 11 lines (kabuli and desi) from the University of Saskatchewan, Saskatoon, SK, Canada. Also, the kabuli cvs. UC27 and Sanford, which were developed in the United States $(6,14)$, were included as susceptible and partially resistant checks, respectively. Based on the results of this initial test, 14 lines were selected for further study. In a second preliminary study, the 14 lines were inoculated with each of 58 isolates from Canada and around the world, in a replicated study to identify the lines that best differentiated groups of isolates.

Five kabuli and three desi lines were selected and used to screen a population of 40 Canadian isolates of $A$. rabiei collected from infected chickpea plants in 25 fields in Saskatchewan from 1997 to 2000. In addition, 18 isolates from other countries were compared with the Canadian isolates (Table 1). Of the 18 foreign isolates, 5 isolates were from Australia, 3 from the United States, 6 from Syria, and 2 each from India and Turkey. Isolates were stored and maintained at $-80^{\circ} \mathrm{C}$ until required.

Seeding and inoculation. In the main study, each chickpea line was seeded in two trials. The first trial consisted of two replicates of each isolate, and each experimental unit consisted of a single pot containing three plants. There were three replicates in the second trial. Seed of each line were sown in a soil-less mix of peat moss, vermiculite, and sand $(2: 2: 1, \mathrm{vol} / \mathrm{vol} / \mathrm{vol})$ and a slow-release granular fertilizer (Osmocote; Scotts-Sierra Horticultural Products Co., Marysville, OH). A noninoculated pot of each line was included as a check. The pots were placed in a greenhouse for 3 weeks at 20 and $16^{\circ} \mathrm{C}$ (day and night, respectively) and a $16-\mathrm{h}$ photoperiod. Seedlings of each line were inoculated with each of the 40 Canadian and 18 foreign single-spored isolates in a suspension of sterile distilled water at $2 \times 10^{5}$ 
conidia $\mathrm{ml}^{-1}$ using an atomizer (DeVilbiss, Somerset, PA). The seedlings were sprayed with the suspension until runoff. Inoculated seedlings were incubated in a mist chamber made of clear polythene plastic located in a growth chamber at 20 and $16^{\circ} \mathrm{C}$ (day and night, respectively) and a 16-h photoperiod with $250 \mu \mathrm{E} \mathrm{m} \mathrm{m}^{-2} \mathrm{~s}^{-1}$ for $48 \mathrm{~h}$, as described by Chongo and Gossen (3). Plants were moved from the mist chamber to an adjacent bench in the same growth chamber and arranged in a randomized complete block design.

A rating scale was developed to combine the quantitative and qualitative nature of disease reaction in this host-pathogen combination. Each plant was rated 14 days after inoculation using a 0-to-9 rating scale, where $0=$ no symptoms; $1=$ few, very small $\left(<2 \mathrm{~mm}^{2}\right)$ lesions on leaves and stems, $<2 \%$ plant area affected (PAA); $2=$ very small $\left(<2 \mathrm{~mm}^{2}\right)$ lesions, $2-5 \%$ PAA; $3=$ many small lesions ( $<2$ to $5 \mathrm{~mm}^{2}$ ), 5 to $10 \%$ PAA; $4=$ many small lesions, few large $\left(>5 \mathrm{~mm}^{2}\right)$ lesions, 10 to $25 \%$ PAA; 5 $=$ many large lesions, 25 to $50 \%$ PAA; $6=$ lesions coalescing, 50 to $75 \%$ PAA, $7=$ lesions coalescing with stem girdling, 75 to 90\% PAA; $8=$ stem girdling or breakage, $>90 \%$ PAA; 9 = plants dead (Fig. 1). No pycnidia were observed on lesions of plants with ratings of 1 to 3 (considered to be nonsporulating lesions), whereas plants with scores from 4 to 9 always produced some lesions with visible pycnidia.

For grouping isolates into pathotypes, the interaction phenotype of each differentialisolate combination on the 0 -to- 9 rating scale was consolidated into two classes as follows: 0 to $3=$ resistant and 4 to $9=$ susceptible. Disease reaction of the differentials also was evaluated using analysis of variance (GLM procedure; SAS Institute, Cary, NC).

RAPD analysis. Thirty-nine A. rabiei isolates from Saskatchewan, Canada, and 20 isolates from other countries $(6$ from Syria, 5 from Australia, 5 from the United States, 2 from Turkey, and 2 from India) were examined (Table 1). In addition, two isolates of $A$. pinodes L. K. Jones (teleomorph: Mycosphaerella pinodes (Berk. \& Bloxam) Vestergr.) from field pea (Pisum sativum L.) and seven of A. lentis Vassilijevsky (teleomorph: D. lentis Kaizer, Wong, \& Rogers) from lentil (Lens curinalis Medik.) were included for comparison. Of the 39 A. rabiei isolates from Canada used in RAPD analysis, 32 were common to those used in the virulence tests. Each isolate was single spored and maintained at $-80^{\circ} \mathrm{C}$ until required.

For DNA extraction, each isolate was grown at room temperature in a 100-ml flask containing $50 \mathrm{ml}$ of commercial potato dextrose broth (Becton Dickinson \& Co., Cockeysville, MD) The flasks were placed on an orbital shaker at $100 \mathrm{rpm}$. Mycelia from 5- to 7-day-old cultures were harvested by filtration and stored in 2-ml vials at $-80^{\circ} \mathrm{C}$. When needed, mycelia were freeze dried for 3 days, after which two plastic beads ( $2 \mathrm{~mm}$ in diameter) were placed in each sample vial and the vials were kept on a shaker (Mixer/Mill 8000; Spex Certiprep, Mechuchen, NJ) for 15 min to pulverize the mycelia into a fine powder. DNA was extracted using a modified minipreparation protocol using the cetyltrimethyl-ammonium bromide method (28). Initially, 75 University of British Columbia (UBC; Vancouver, BC, Canada) decamer primers and 2 Operon Technologies, Inc. (OP; Almeda, Ca) decamer primers were screened for polymorphism using 10 isolates of A. rabiei. Eight of the primers, UBC-702 (5' GGGAGAAGGG 3'), UBC-708 (5' GGGTTGTGGG 3'), UBC726 (5' GGTGTGGGTG 3'), UBC-727 (5' GGGTGTGGTG 3'), UBC-731 (5' CCCACACCAC 3'), UBC-739 (5' GGAGGGAGAG 3'), UBC-740 (5' GGAGGGAGGA $3^{\prime}$ ) and OP-C18 (5' TGAGTGGGTG $3^{\prime}$ ), were selected and used to screen the whole population of isolates.

The DNA of each isolate was amplified in $20 \mu \mathrm{l}$ of a solution made up of $5.8 \mu \mathrm{l}$ of sterile double-deionized $\mathrm{H}_{2} \mathrm{O}, 2 \mu \mathrm{l}$ of $10 \times$ Tris-acetate-EDTA (TAE) buffer, $2 \mu \mathrm{l}$ of 25 $\mathrm{mM} \mathrm{MgCl} 2,2 \mu \mathrm{l}$ of $2 \mathrm{mM}$ dNTPs, $0.2 \mu \mathrm{l}$ of Taq DNA polymerase ( $5 \mathrm{U} / \mu \mathrm{l}$; Fisher Scientific, Nepean, ON, Canada), $4 \mu \mathrm{l}$ of 1 $\mathrm{mM}$ primer, and $4 \mu \mathrm{l}$ of $10 \mathrm{ng}$ liter $^{-1}$ genomic DNA. Amplifications were performed using two thermal cyclers (Peltier Thermal Cycler PTC 200; MJ Research Inc., Watertown, MA and Gene Amp PCR System 9700; PE Applied Biosystems, Norwalk, CT), each with an initial denaturation step for $5 \mathrm{~min}$ at $94^{\circ} \mathrm{C}$, followed by 35 cycles of $30 \mathrm{~s}$ at $94^{\circ} \mathrm{C}, 30 \mathrm{~s}$ at $37^{\circ} \mathrm{C}$, and $30 \mathrm{~s}$ at $72^{\circ} \mathrm{C}$, with a final extension for 7 min at $72^{\circ} \mathrm{C}$. Amplified products were separated by electrophoresis in $2 \%$ agarose in $1 \times$ TAE buffer. For each primer and isolate combination, the amplification reactions were performed two times in each polymerase chain reaction (PCR) machine to determine the reliability and reproducibility of the method. Reactions were kept at $4^{\circ} \mathrm{C}$ until gel electrophoresis was performed. In each gel, a 1-kb Plus DNA ladder (Gibco BRL, Gathersburg, MD) was used as a molecular reference marker. Gels were stained in ethidium bromide for $20 \mathrm{~min}$ and then destained in tap water. Fragments of DNA were visualized and photographed under transmitted ultraviolet light.

Using all eight primers, cluster analysis was performed on the 68 isolates (59 of $A$. rabiei, 7 of $A$. lentis, and 2 of $A$. pinodes). These isolates produced a total of 112 fragments. For each isolate and primer combination, a binary number system was used to score the bands, with 0 indicating absence and 1 the presence of bands, regardless of band intensity. A similarity matrix was constructed using Jaccard's coefficient in the SIMQUAL program of the Numerical Taxonomy and Multivariate
Table 1. Isolates of Ascochyta rabiei, A. lentis, and A. pinodes ${ }^{\mathrm{a}}$

\begin{tabular}{|c|c|c|}
\hline Number & Isolate & Origin \\
\hline \multicolumn{3}{|l|}{ A.rabiei } \\
\hline 1 & Jan9702 & Canada \\
\hline 2 & Mar9703 & Canada \\
\hline 3 & Jan9804 & Canada \\
\hline 4 & Jan9805 & Canada \\
\hline 5 & May9804 & Canada \\
\hline 6 & Jul9803 & Canada \\
\hline 7 & Jul9804 & Canada \\
\hline 8 & Jul9805 & Canada \\
\hline 9 & Jul9806 & Canada \\
\hline 10 & Jul9807 & Canada \\
\hline 11 & Jul9808 & Canada \\
\hline 12 & Jul9809 & Canada \\
\hline 13 & Jul9810 & Canada \\
\hline 14 & Jul9813 & Canada \\
\hline 15 & Jul9814 & Canada \\
\hline 16 & Jul9815 & Canada \\
\hline 17 & Jul9816 & Canada \\
\hline 18 & Jul9818 & Canada \\
\hline 19 & Sep9804 & Canada \\
\hline 20 & Sep9806 & Canada \\
\hline 21 & Oct9804 & Canada \\
\hline 22 & Oct9805 & Canada \\
\hline 23 & Oct9806 & Canada \\
\hline 24 & Oct9809 & Canada \\
\hline 25 & Nov9803 & Canada \\
\hline 26 & Nov9804 & Canada \\
\hline 27 & Nov9805 & Canada \\
\hline 28 & Nov9806 & Canada \\
\hline 29 & Nov9807 & Canada \\
\hline 30 & Nov9808 & Canada \\
\hline 31 & Jan9907 & Canada \\
\hline 32 & Feb9914 & Canada \\
\hline 33 & Feb9917 & Canada \\
\hline 34 & Feb9923 & Canada \\
\hline 35 & Feb9924 & Canada \\
\hline 36 & Mar9901 & Canada \\
\hline 37 & Mar9903 & Canada \\
\hline 38 & Mar9906 & Canada \\
\hline 39 & Mar9912 & Canada \\
\hline 95 & Feb9710 & Canada \\
\hline 96 & Feb9803 & Canada \\
\hline 97 & Jul9811 & Canada \\
\hline 98 & Jul9812 & Canada \\
\hline 99 & Aug9803 & Canada \\
\hline 100 & Oct9808 & Canada \\
\hline 101 & Dec9804 & Canada \\
\hline 102 & Jan0001 & Canada \\
\hline 54 & Race 1 & Syria \\
\hline 55 & Race 2 & Syria \\
\hline 56 & Race 3 & Syria \\
\hline 57 & Race 4 & Syria \\
\hline 58 & Race 5 & Syria \\
\hline 59 & Race 6 & Syria \\
\hline 60 & Ank 1 & Turkey \\
\hline 61 & Ank 3 & Turkey \\
\hline 62 & Ab-4 & India \\
\hline 63 & Ab-1 & India \\
\hline 64 & Ar-483 & United States \\
\hline 65 & Ar-490 & United States \\
\hline 66 & Ar-731 & United States \\
\hline 67 & ATCC 76501 & United States \\
\hline 68 & ATCC 76502 & United States \\
\hline 69 & Sep0011 & Australia \\
\hline 70 & Sep0012 & Australia \\
\hline 71 & Sep0013 & Australia \\
\hline 72 & Sep0014 & Australia \\
\hline \multirow{2}{*}{\multicolumn{3}{|c|}{ A. lentis }} \\
\hline & & \\
\hline 74 & Mar0011 & Canada \\
\hline 75 & Mar0012 & Canada \\
\hline 76 & Mar0013 & Canada \\
\hline 77 & Mar0015 & Canada \\
\hline 78 & Mar0016 & Canada \\
\hline 79 & Mar0017 & Canada \\
\hline 80 & Mar0020 & Canada \\
\hline \multicolumn{3}{|c|}{ A. pinodes } \\
\hline 91 & Sep0017 & Canada \\
\hline 92 & Sep0018 & Canada \\
\hline
\end{tabular}

a Isolates in bold were used in virulence tests. Isolates 1 to 92 were used in random amplified polymorphic DNA analysis. 
Analysis System (NTSYS-pc) software (22). The resulting similarity data was used to construct a dendrogram using the unweighted pairgroup method with arithmetic averages in the SAHN program within the NTSYS-pc software. Bootstrap support for branches was conducted on 1,000 samples using the WINBOOT program (30).

\section{RESULTS}

Virulence study. During the initial screening of 62 chickpea lines to select a differential set, several factors were considered. Only lines that produced consistent disease reactions were selected, to eliminate lines that still were segregating for resistance genes, and, when several lines came from similar parental source

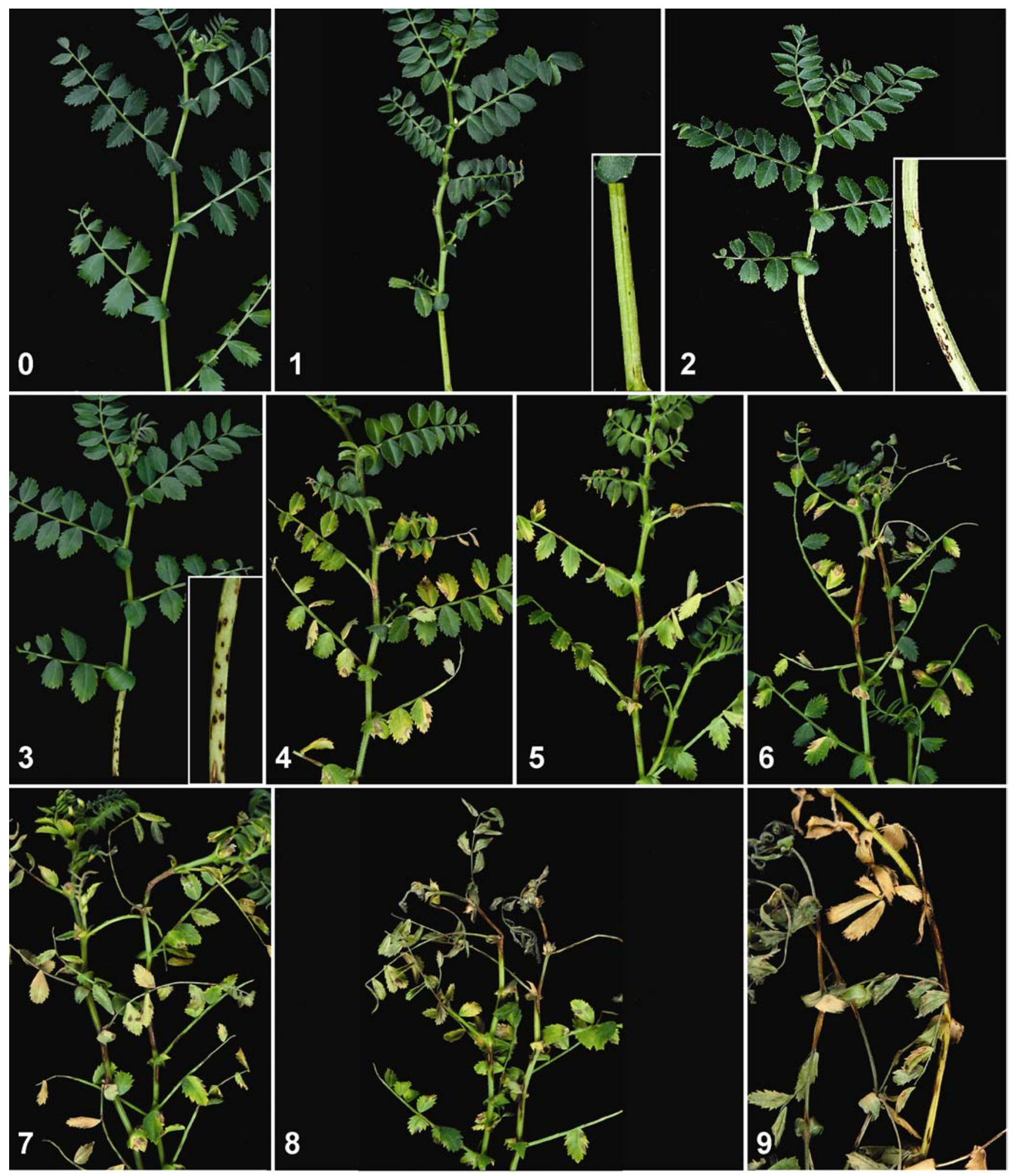

Fig. 1. Rating scale for Ascochyta blight in chickpea caused by Ascochyta rabiei: $0=$ no symptoms; $1=$ few, very small $\left(<2 \mathrm{~mm}^{2}\right)$ lesions on leaves or stems, $<2 \%$ plant area affected (PAA); $2=$ very small $\left(<2 \mathrm{~mm}^{2}\right)$ lesions, 2 to $5 \%$ PAA; $3=$ many small lesions $\left(\leq 2\right.$ to $\left.5 \mathrm{~mm}^{2}\right), 5$ to $10 \%$ PAA; $4=$ many small lesions, few large $\left(>5 \mathrm{~mm}^{2}\right)$ lesions, 10 to $25 \%$ PAA; $5=$ many large lesions, 25 to $50 \%$ PAA; $6=$ lesions coalescing, 50 to $75 \%$ PAA; $7=$ lesions coalescing with stem girdling, 75 to $90 \%$ PAA; $8=$ stem girdling and breakage, $>90 \%$ PAA; and $9=$ plants dead. Lesions on plants rated as 1 to 3 produced no visible pycnidia, but plants rated as 4 to 9 produced lesions with visible pycnidia and sporulation. 
material, only the one with the clearest and most consistent pattern of differential reaction was selected. Lines that readily set seed under controlled conditions were preferred, to ensure a consistent supply of uniform seed in future tests. The eight lines that were selected as differentials were kabuli lines UC27, Sanford, ILC 3856, ILC 4421, and Flip 83-48, and desi lines ICC 4200, ICC 4475, and ICC 6328.

In analysis of variance, the interaction of line and isolate was significant (not shown). Based on this differential interaction, 14 pathotypes were identified among the Canadian isolates (Tables 2 and 3). One pathotype was only weakly virulent irrespective of differential line assessed, while others were virulent on as many as six differentials. The desi lines were resistant to a wider range of isolates than the kabuli lines.

Pathotype 1, which was represented by three Canadian isolates, was not virulent on any line (Tables 2 and 3). Pathotype 2 was virulent only on cv. UC27. It was the most common pathotype collected (eight isolates), and was found in 7 of 25 fields (data not shown). Pathotype 4 (five isolates) was virulent on UC27, ICC 4200, and ICC 4475. Cv. Sanford, which lost its position as the dominant cultivar in the region in 1999 to 2000 due to declining levels of resistance, was susceptible to pathotypes $6,7,8,9,10,12$, and 13 (16 isolates).

Table 3. Disease reaction and pathotype groupings of 40 isolates of Ascochyta rabiei from Saskatchewan, Canada on five kabuli and three desi chickpea differential lines ${ }^{\mathrm{a}}$

\begin{tabular}{|c|c|c|c|c|c|c|c|c|c|}
\hline \multirow[b]{2}{*}{ Pathotype } & \multirow[b]{2}{*}{ No. ${ }^{b}$} & \multicolumn{8}{|c|}{ Differential line or cultivar } \\
\hline & & $\begin{array}{c}\mathrm{UC} \\
27\end{array}$ & $\begin{array}{c}\text { ICC } \\
4200^{c}\end{array}$ & $\begin{array}{c}\text { ICC } \\
4475^{c}\end{array}$ & $\begin{array}{c}\text { ICC } \\
6328^{c}\end{array}$ & Sanford & $\begin{array}{l}\text { ILC } \\
3856\end{array}$ & $\begin{array}{l}\text { FLIP } \\
83-48\end{array}$ & $\begin{array}{l}\text { ILC } \\
4421\end{array}$ \\
\hline$\overline{1}$ & 3 & $\mathrm{R}$ & $\mathrm{R}$ & $\mathrm{R}$ & $\mathrm{R}$ & $\mathrm{R}$ & $\mathrm{R}$ & $\mathrm{R}$ & $\mathrm{R}$ \\
\hline 2 & 8 & $\mathrm{~S}$ & $\mathrm{R}$ & $\mathrm{R}$ & $\mathrm{R}$ & $\mathrm{R}$ & $\mathrm{R}$ & $\mathrm{R}$ & $\mathrm{R}$ \\
\hline 3 & 3 & $\mathrm{~S}$ & $\mathrm{~S}$ & $\mathrm{R}$ & $\mathrm{R}$ & $\mathrm{R}$ & $\mathrm{R}$ & $\mathrm{R}$ & $\mathrm{R}$ \\
\hline 4 & 5 & $\mathrm{~S}$ & $\mathrm{~S}$ & $\mathrm{~S}$ & $\mathrm{R}$ & $\mathrm{R}$ & $\mathrm{R}$ & $\mathrm{R}$ & $\mathrm{R}$ \\
\hline 5 & 1 & $\mathrm{~S}$ & $\mathrm{~S}$ & $\mathrm{~S}$ & $\mathrm{~S}$ & $\mathrm{R}$ & $\mathrm{R}$ & $\mathrm{R}$ & $\mathrm{R}$ \\
\hline 6 & 3 & $\mathrm{~S}$ & $\mathrm{~S}$ & $\mathrm{~S}$ & $\mathrm{~S}$ & $\mathrm{~S}$ & $\mathrm{R}$ & $\mathrm{R}$ & $\mathrm{R}$ \\
\hline 7 & 1 & $\mathrm{~S}$ & $\mathrm{~S}$ & $\mathrm{~S}$ & $\mathrm{~S}$ & $\mathrm{~S}$ & $\mathrm{~S}$ & $\mathrm{R}$ & $\mathrm{R}$ \\
\hline 8 & 2 & $\mathrm{~S}$ & $\mathrm{~S}$ & $\mathrm{R}$ & $\mathrm{R}$ & $\mathrm{S}$ & $\mathrm{R}$ & $\mathrm{R}$ & $\mathrm{R}$ \\
\hline 9 & 3 & $\mathrm{~S}$ & $\mathrm{~S}$ & $\mathrm{~S}$ & $\mathrm{R}$ & $\mathrm{S}$ & $\mathrm{R}$ & $\mathrm{R}$ & $\mathrm{R}$ \\
\hline 10 & 2 & $\mathrm{~S}$ & $\mathrm{~S}$ & $\mathrm{~S}$ & $\mathrm{R}$ & $\mathrm{S}$ & $\mathrm{R}$ & $\mathrm{S}$ & $\mathrm{R}$ \\
\hline 11 & 3 & $\mathrm{~S}$ & $\mathrm{R}$ & $\mathrm{S}$ & $\mathrm{R}$ & $\mathrm{R}$ & $\mathrm{R}$ & $\mathrm{R}$ & $\mathrm{R}$ \\
\hline 12 & 1 & $\mathrm{~S}$ & $\mathrm{R}$ & $\mathrm{S}$ & $\mathrm{R}$ & $\mathrm{S}$ & $\mathrm{R}$ & $\mathrm{R}$ & $\mathrm{R}$ \\
\hline 13 & 4 & $\mathrm{~S}$ & $\mathrm{R}$ & $\mathrm{R}$ & $\mathrm{R}$ & $\mathrm{S}$ & $\mathrm{R}$ & $\mathrm{R}$ & $\mathrm{R}$ \\
\hline 14 & 1 & $\mathrm{~S}$ & $\mathrm{R}$ & $\mathrm{R}$ & $\mathrm{R}$ & $\mathrm{R}$ & $\mathrm{S}$ & $\mathrm{R}$ & $\mathrm{R}$ \\
\hline
\end{tabular}

${ }^{\text {a }}$ Based on a 0 -to-9 scale where 0 to $3=$ resistant $(\mathrm{R})$ and 4 to $9=$ susceptible $(\mathrm{S})$.

b Number of isolates.

c Desi chickpea line.

Table 2. Mean disease scores ( \pm standard error) for 40 isolates of Ascochyta rabiei from Saskatchewan, Canada on five kabuli and three desi chickpea differential lines ${ }^{\mathrm{a}}$

\begin{tabular}{|c|c|c|c|c|c|c|c|c|c|}
\hline \multirow[b]{2}{*}{ Pathotype } & \multirow[b]{2}{*}{ Isolate } & \multicolumn{8}{|c|}{ Differential line } \\
\hline & & UC27 & $\mathrm{ICC4200}^{\mathrm{b}}$ & $\mathrm{ICC}_{4475^{b}}$ & ICC6328 $^{b}$ & Sanford & ILC3856 & FLIP83-48 & ILC4421 \\
\hline \multirow[t]{3}{*}{1} & Nov9803 & $2.0 \pm 0$ & $1.6 \pm 0.1$ & $1.8 \pm 0.2$ & $1.0 \pm 0$ & $1.0 \pm 0$ & $1.0 \pm 0$ & $1.0 \pm 0$ & $1.0 \pm 0$ \\
\hline & Jul9815 & $3.0 \pm 0$ & $1.0 \pm 0$ & $1.0 \pm 0$ & $1.0 \pm 0$ & $1.0 \pm 0$ & $1.0 \pm 0$ & $1.0 \pm 0$ & $1.0 \pm 0$ \\
\hline & Jul9816 & $2.0 \pm 0$ & $1.4 \pm 0.1$ & $1.6 \pm 0.1$ & $1.4 \pm 0.1$ & $1.0 \pm 0$ & $1.0 \pm 0$ & $1.0 \pm 0$ & $1.0 \pm 0$ \\
\hline \multirow[t]{8}{*}{2} & Nov9807 & $8.0 \pm 0.2$ & $2.2 \pm 0.2$ & $1.8 \pm 0.2$ & $2.0 \pm 0.1$ & $2.2 \pm 0.2$ & $0.6 \pm 0.1$ & $1.2 \pm 0.1$ & $0.8 \pm 0.1$ \\
\hline & Dec9804 & $8.0 \pm 0$ & $1.0 \pm 0$ & $1.6 \pm 0.1$ & $1.0 \pm 0$ & $1.0 \pm 0$ & $0.6 \pm 0.1$ & $1.0 \pm 0$ & $1.0 \pm 0$ \\
\hline & Nov9806 & $6.2 \pm 0.4$ & $2.6 \pm 0.1$ & $1.6 \pm 0.1$ & $0.2 \pm 0.1$ & $1.0 \pm 0.1$ & $0.6 \pm 0.1$ & $0.6 \pm 0.1$ & $0 \pm 0$ \\
\hline & Feb9914 & $8.0 \pm 0$ & $2.6 \pm 0.1$ & $2.0 \pm 0$ & $1.0 \pm 0$ & $2.4 \pm 0.1$ & $0.4 \pm 0.1$ & $1.0 \pm 0$ & $1.0 \pm 0$ \\
\hline & Sep9806 & $7.8 \pm 0.2$ & $1.6 \pm 0.1$ & $2.0 \pm 0.1$ & $1.6 \pm 0.2$ & $1.6 \pm 0.1$ & $0.8 \pm 0.1$ & $1.2 \pm 0.1$ & $0.8 \pm 0.1$ \\
\hline & Nov9805 & $8.0 \pm 0$ & $1.8 \pm 0.2$ & $1.4 \pm 0.1$ & $1.4 \pm 0.1$ & $1.8 \pm 0.2$ & $1.4 \pm 0.1$ & $1.4 \pm 0.1$ & $1.0 \pm 0$ \\
\hline & Mar9703 & $8.6 \pm 0.1$ & $2.6 \pm 0.1$ & $1.0 \pm 0$ & $2.0 \pm 0$ & $1.0 \pm 0$ & $1.0 \pm 0$ & $1.0 \pm 0$ & $1.0 \pm 0$ \\
\hline & Jan9907 & $8.0 \pm 0$ & $0.4 \pm 0.1$ & $1.0 \pm 0$ & $1.0 \pm 0$ & $1.0 \pm 0$ & $1.0 \pm 0$ & $1.0 \pm 0$ & $1.0 \pm 0$ \\
\hline \multirow[t]{3}{*}{3} & Oct9805 & $7.4 \pm 0.1$ & $5.2 \pm 0.2$ & $2.6 \pm 0.1$ & $1.6 \pm 0.1$ & $1.6 \pm 0.1$ & $2.0 \pm 0$ & $1.4 \pm 0.1$ & $0.0 \pm 0$ \\
\hline & Feb9803 & $7.4 \pm 0.1$ & $4.0 \pm 0$ & $2.4 \pm 0.1$ & $1.0 \pm 0$ & $1.4 \pm 0.1$ & $2.0 \pm 0$ & $1.0 \pm 0$ & $1.0 \pm 0$ \\
\hline & $\operatorname{Jan} 0001$ & $9.0 \pm 0$ & $4.6 \pm 0.1$ & $2.0 \pm 0$ & $2.4 \pm 0.1$ & $2.0 \pm 0$ & $2.0 \pm 0$ & $1.0 \pm 0$ & $1.0 \pm 0$ \\
\hline \multirow[t]{5}{*}{4} & Ju19812 & $8.0 \pm 0$ & $4.4 \pm 0.1$ & $5.4 \pm 0.1$ & $2.4 \pm 0.1$ & $2.4 \pm 0.1$ & $1.4 \pm 0.1$ & $1.4 \pm 0.1$ & $1.4 \pm 0.1$ \\
\hline & Jul9807 & $7.6 \pm 0.2$ & $4.8 \pm 0.2$ & $4.0 \pm 0.1$ & $0.8 \pm 0.2$ & $2.8 \pm 0.1$ & $1.0 \pm 0$ & $1.0 \pm 0.1$ & $1.2 \pm 0.1$ \\
\hline & Jul9806 & $7.6 \pm 0.1$ & $4.4 \pm 0.2$ & $4.4 \pm 0.1$ & $1.8 \pm 0.2$ & $2.4 \pm 0.2$ & $0.8 \pm 0.1$ & $1.2 \pm 0.1$ & $0.6 \pm 0.1$ \\
\hline & Aug9803 & $8.4 \pm 0.1$ & $5.2 \pm 0.2$ & $6.6 \pm 0.1$ & $2.4 \pm 0.1$ & $2.0 \pm 0$ & $2.0 \pm 0$ & $2.6 \pm 0.1$ & $2.0 \pm 0$ \\
\hline & Jan9702 & $8.6 \pm 0.1$ & $4.4 \pm 0.1$ & $4.8 \pm 0.1$ & $1.6 \pm 0.2$ & $2.4 \pm 0.1$ & $1.0 \pm 0.3$ & $1.4 \pm 0.1$ & $0.4 \pm 0.1$ \\
\hline \multirow[t]{3}{*}{5} & May9804 & $8.6 \pm 0.1$ & $4.2 \pm 0.2$ & $4.2 \pm 0.1$ & $4.2 \pm 0.1$ & $4.4 \pm 0.1$ & $0.6 \pm 0.2$ & $1.4 \pm 0.2$ & $0.4 \pm 0.1$ \\
\hline & Jul9808 & $8.6 \pm 0.1$ & $4.2 \pm 0.1$ & $5.0 \pm 0.2$ & $4.0 \pm 0$ & $5.2 \pm 0.2$ & $1.2 \pm 0.2$ & $0.8 \pm 0.1$ & $1.2 \pm 0.2$ \\
\hline & Jan9805 & $8.4 \pm 0.1$ & $4.4 \pm 0.1$ & $6.0 \pm 0$ & $4.2 \pm 0.1$ & $4.2 \pm 0.1$ & $2.4 \pm 0.1$ & $1.0 \pm 0$ & $2.4 \pm 0.1$ \\
\hline \multirow[t]{3}{*}{6} & Ju19804 & $8.4 \pm 0.1$ & $4.2 \pm 0.1$ & $4.4 \pm 0.1$ & $1.4 \pm 0.1$ & $4.6 \pm 0.1$ & $1.6 \pm 0.1$ & $1.0 \pm 0$ & $1.0 \pm 0$ \\
\hline & Feb9710 & $8.4 \pm 0.2$ & $4.2 \pm 0.1$ & $4.0 \pm 0$ & $1.0 \pm 0.2$ & $4.0 \pm 0$ & $0.8 \pm 0.2$ & $1.4 \pm 0.1$ & $1.0 \pm 0.1$ \\
\hline & Ju19811 & $8.8 \pm 0.1$ & $4.0 \pm 0$ & $4.6 \pm 0.2$ & $2.0 \pm 0$ & $3.5 \pm 0.1$ & $2.2 \pm 0.1$ & $1.2 \pm 0.1$ & $2.0 \pm 0$ \\
\hline 7 & Jul9809 & $8.8 \pm 0.1$ & $5.0 \pm 0$ & $5.8 \pm 0.1$ & $4.8 \pm 0.1$ & $6.0 \pm 0$ & $4.0 \pm 0$ & $1.8 \pm 0.1$ & $1.8 \pm 0.1$ \\
\hline \multirow[t]{3}{*}{8} & Jul9805 & $8.0 \pm 0$ & $2.2 \pm 0.1$ & $6.0 \pm 0$ & $2.2 \pm 0.1$ & $2.0 \pm 0$ & $2.2 \pm 0.1$ & $1.2 \pm 0.1$ & $1.0 \pm 0$ \\
\hline & Jan9804 & $8.6 \pm 0.1$ & $2.0 \pm 0$ & $4.6 \pm 0.1$ & $1.0 \pm 0$ & $2.0 \pm 0$ & $1.0 \pm 0$ & $1.0 \pm 0$ & $1.0 \pm 0$ \\
\hline & Oct9806 & $7.8 \pm 0.1$ & $2.0 \pm 0$ & $4.2 \pm 0.1$ & $1.6 \pm 0.1$ & $2.2 \pm 0.2$ & $0.6 \pm 0.1$ & $1.4 \pm 0.1$ & $1.2 \pm 0.1$ \\
\hline \multirow[t]{4}{*}{9} & Oct9808 & $7.6 \pm 0.1$ & $1.4 \pm 0.1$ & $1.8 \pm 0$ & $1.0 \pm 0.1$ & $6.0 \pm 0.1$ & $1.0 \pm 0.2$ & $0.8 \pm 0.1$ & $1.0 \pm 0$ \\
\hline & Oct9809 & $8.6 \pm 0.1$ & $1.6 \pm 0.1$ & $2.0 \pm 0.1$ & $1.4 \pm 0.1$ & $4.4 \pm 0$ & $2.2 \pm 0.1$ & $1.6 \pm 0.1$ & $1.0 \pm 0$ \\
\hline & Jul9814 & $7.4 \pm 0$ & $2.2 \pm 0.1$ & $3.0 \pm 0.1$ & $2.0 \pm 0$ & $5.4 \pm 0$ & $2.8 \pm 0.1$ & $2.0 \pm 0$ & $1.0 \pm 0.1$ \\
\hline & Jul9818 & $8.0 \pm 0.2$ & $1.4 \pm 0.1$ & $2.4 \pm 0$ & $2.0 \pm 0$ & $4.0 \pm 0.2$ & $1.6 \pm 0.1$ & $2.0 \pm 0$ & $1.6 \pm 0.1$ \\
\hline 10 & Jul9803 & $7.8 \pm 0.2$ & $2.2 \pm 0.2$ & $1.0 \pm 0$ & $1.0 \pm 0$ & $1.0 \pm 0$ & $4.8 \pm 0.2$ & $0.6 \pm 0.1$ & $1.0 \pm 0.1$ \\
\hline \multirow[t]{2}{*}{11} & Sep9804 & $7.4 \pm 0.1$ & $4.8 \pm 0.2$ & $2.8 \pm 0.1$ & $0.6 \pm 0.1$ & $4.4 \pm 0.1$ & $1.2 \pm 0.3$ & $1.2 \pm 0.1$ & $0.6 \pm 0.2$ \\
\hline & Oct9804 & $7.4 \pm 0.1$ & $4.0 \pm 0$ & $1.0 \pm 0$ & $2.0 \pm 0$ & $3.8 \pm 0.2$ & $2.0 \pm 0$ & $1.4 \pm 0.1$ & $1.0 \pm 0$ \\
\hline 12 & Jul9813 & $8.6 \pm 0.1$ & $1.6 \pm 0.1$ & $5.4 \pm 0.1$ & $2.4 \pm 0.1$ & $6.0 \pm 0$ & $1.4 \pm 0.1$ & $1.6 \pm 0.1$ & $2.0 \pm 0$ \\
\hline \multirow[t]{2}{*}{13} & Nov9808 & $9.0 \pm 0$ & $4.6 \pm 0.1$ & $4.4 \pm 0.1$ & $1.0 \pm 0$ & $4.6 \pm 0.1$ & $2.6 \pm 0.1$ & $4.0 \pm 0$ & $1.0 \pm 0$ \\
\hline & Feb9923 & $8.0 \pm 0$ & $4.0 \pm 0$ & $4.4 \pm 0.1$ & $3.0 \pm 0$ & $4.0 \pm 0$ & $1.0 \pm 0$ & $4.0 \pm 0$ & $0.4 \pm 0.1$ \\
\hline 14 & Jul9810 & $8.0 \pm 0$ & $4.2 \pm 0.1$ & $6.6 \pm 0.1$ & $4.6 \pm 0.1$ & $2.6 \pm 0.1$ & $1.6 \pm 0.1$ & $1.0 \pm 0$ & $2.0 \pm 0$ \\
\hline
\end{tabular}

a Based on a 0 -to- 9 rating scale where $0=$ no symptoms and $9=$ plants dead.

b Desi chickpea line. 
The small-seeded kabuli lines ILC 4421, broader range of resistance than the largeNone of the isolates were virulent on line ILC 4421, and two were virulent on each of Flip 83-48 and ILC 3856 (Tables 2 and 3 ). None of the desi lines were susceptible to pathotypes $1,2,13$, and 14 , but all were susceptible to pathotypes 5,6 , and 7 . Lines ICC 4200, ICC4475, and ICC6328 were susceptible to 20,19 , and 5 of the isolates, respectively (Tables 2 and 3). Of 18 isolates from other countries, 17 were distributed among the pathotypes differentiated with Canadian isolates (data not shown).

RAPD analysis. Only the reproducible When tested on the isolates of A. rabiei, A. lentis, and $A$. pinodes, the eight primers produced 112 fragments, of which 96\% were polymorphic. However, only the results of representative isolates for two primers, UBC-702 and UBC-727, are shown (Fig. 2A and B). Isolates of $A$. rabiei from Canada produced at least seven banding patterns, but 30 of $39(77 \%) \mathrm{Ca}-$ nadian isolates fell into three banding patterns, represented by isolates 2,6 , and 25 (Fig. 2A and B). Many of the international isolates produced the same banding pattern as the Canadian isolates represented by isolate 2, including five of five isolates from Australia, three of five isolates from the United States, and three of six isolates from Syria. Both isolates from Turkey displayed banding patterns different from those produced by any isolate from Canada (Fig. 1).

Several isolates of A. rabiei clustered in one large group at the 0.66 level of similarity, and there were at least three other small clusters, each with 2 to 4 isolates (Fig. 3). The level of similarity among $A$. rabiei isolates from Canada varied from 0.2 to 1.0 (Fig. 3). The dendrogram from the RAPD data showed that most of the ILC 3856, and Flip 83-48 exhibited a seeded kabuli cvs. Sanford and UC27. RAPD bands were scored. for each primer.

international isolates of $A$. rabiei clustered with a large cluster of $A$. rabie $i$ isolates from Canada and with other isolates from the same geographic origin (Fig. 3). Isolates of A. lentis formed a single tight cluster, with six of the seven isolates showing 0.85 similarity, and showed some similarity (mean 0.45 ) to A. rabiei (Fig. 3). The two isolates of $A$. pinodes showed a similarity level of 0.14 to $A$. rabiei (Fig. 3).

\section{DISCUSSION}

Among isolates from Canada, 14 pathotype groups were identified on eight differentials. Although only 40 isolates were assessed, this study demonstrated that there is a broad range of variation for virulence in the Canadian population of A. rabiei, which supports reports of substantial variations in $A$. rabiei populations in other countries $(7,15,18-20,27)$. The chickpea differentials and rating scale used in the present study were different from those used in other studies; therefore, it is not possible to compare the results directly. In the present study, the differential set included either lines that were being used in the region or those that were potential sources of resistance. The rating scale was designed to take into consideration both the quantitative and qualitative aspects of the disease reaction phenotypes. The differentials and rating scale developed in this study will permit plant pathologists and breeders in the northern Great Plains to identify and monitor pathotypes that are important in this region.

Cv. Sanford is one of the few chickpea cultivars that is adapted to the short growing season of the Canadian prairies, and that also carries resistance to Ascochyta blight. Disease progress on Sanford is slow in young plants, but susceptibility increases over time in adult plants, especially after flowering (3). It was the most commonly grown cultivar in the northern Great

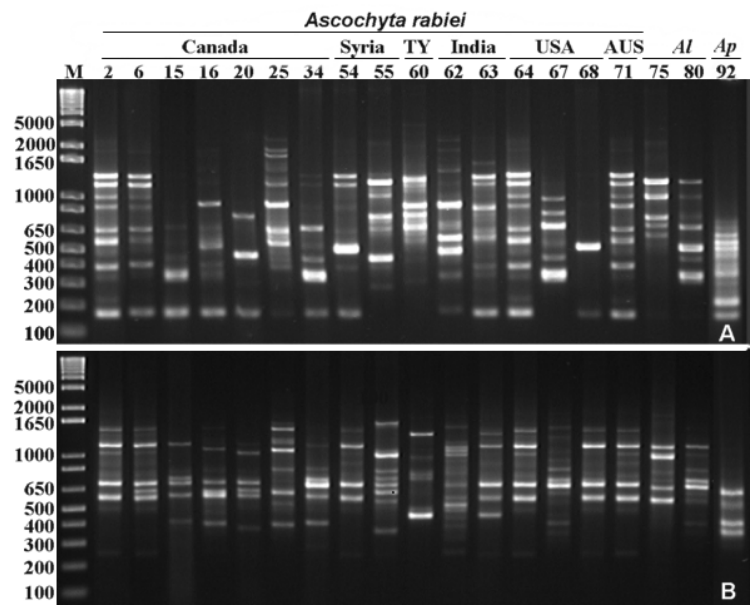

Fig. 2. Random amplified polymorphic DNA banding patterns of Ascochyta rabiei (lanes 2-17) from Canada, Syria, Turkey, India, the United States, and Australia. A. lentis (A1, lanes 18-19) and A. pinodes (Ap, lane 20) generated by $\mathbf{A}$, primer UBC-702 and $\mathbf{B}, \mathrm{UBC}-727 . \mathbf{M}=$ molecular marker; numbers represent isolates in Table 1.
Plains region in the late 1990s. However, our results suggest that its future as a resistant cultivar in the region is limited, because it was susceptible to a high proportion of the Canadian isolates assessed. Line ILC 4421 was resistant to all of the isolates in the study, but has been reported to be susceptible at other sites around the world (21). This difference in disease reaction among sites almost certainly is due to differences in virulence in local pathogen populations. Lines ILC 4421 and Flip 83-48 (susceptible to only 1 of 14 pathotypes) also represent potential sources of resistance for use in the northern Great Plains. The reaction of these lines needs to be assessed against a larger population of isolates and in the field before a major effort is made to incorporate resistance from these sources into adapted chickpea lines.

Analysis using RAPD markers revealed a broad genotypic variation among the 39 Canadian isolates of $A$. rabiei, even though most of the isolates fell into a single large group in cluster analysis. The range of variation in the Canadian isolates covered the range detected in 18 of 20 isolates from around the world. The only exceptions were two isolates from Turkey, which had a unique banding pattern. The wide range in genotypic variation in this relatively small sample of Canadian isolates demonstrates that the source population is highly variable. The narrower range of variation observed among the foreign isolates is likely due, in part, to the larger number of Canadian isolates relative to those from other countries. Isolates of $A$. lentis formed a group that was moderately similar to one cluster of $A$. rabiei isolates, but $A$. pinodes showed little similarity to A. rabiei. This supports the taxonomic treatment for these pathogens, which places the teleomorphs of $A$. rabiei and A. lentis in the genus $D i$ dymella (10) and the teleomorph of $A$. pinodes in Mycosphaerella.

Although certain pathotypes clustered together (e.g., pathotypes 1, 2, and 5) and showed some correspondence between the virulence and RAPD data, the association between RAPD banding patterns and pathotype groups was weak. Although it is possible that a strong association between virulence and RAPD data might be obtained by increasing the population size of isolates, previous studies have failed to show a correlation between RAPD and pathotype groups on other populations of A. rabiei $(5,12,15,23,27)$. The time of collection had no clear effect on pathotype and RAPD groups. This could be attributed to the small population of isolates tested (the bulk of which were collected in a single year). Also, chickpea was a relatively new crop, and production was focused in Saskatchewan and dominated by the cvs. Sanford and Myles.

Chickpea was introduced fairly recently as a field crop in Canada, the United States, and Australia. A. rabiei is transmit- 
ted readily from infested seed (17), and probably was introduced into North America with seed imported from traditional production centers $(8,13,29)$. Therefore, the wide range in genotypic variation among isolates in the northern Great Plains probably reflects the variability of pathogen populations in these countries of origin. In the present study, a specific am- plification pattern observed among many isolates from Canada was similar to the pattern observed among isolates from the United States, Syria, India, and Australia. This observation supports the hypothesis that populations of A. rabiei in Canada, the United States, and Australia were introduced from Syria and India, where chickpea traditionally has been grown.
This study demonstrates that there is a high level of genotypic diversity among isolates of A. rabiei in Canada. The combination of high genotypic diversity and potential for sexual recombination increases the likelihood that rare pathotypes will quickly increase and overcome new sources of resistance as they are developed. Dispersal of the pathogen by airborne as-

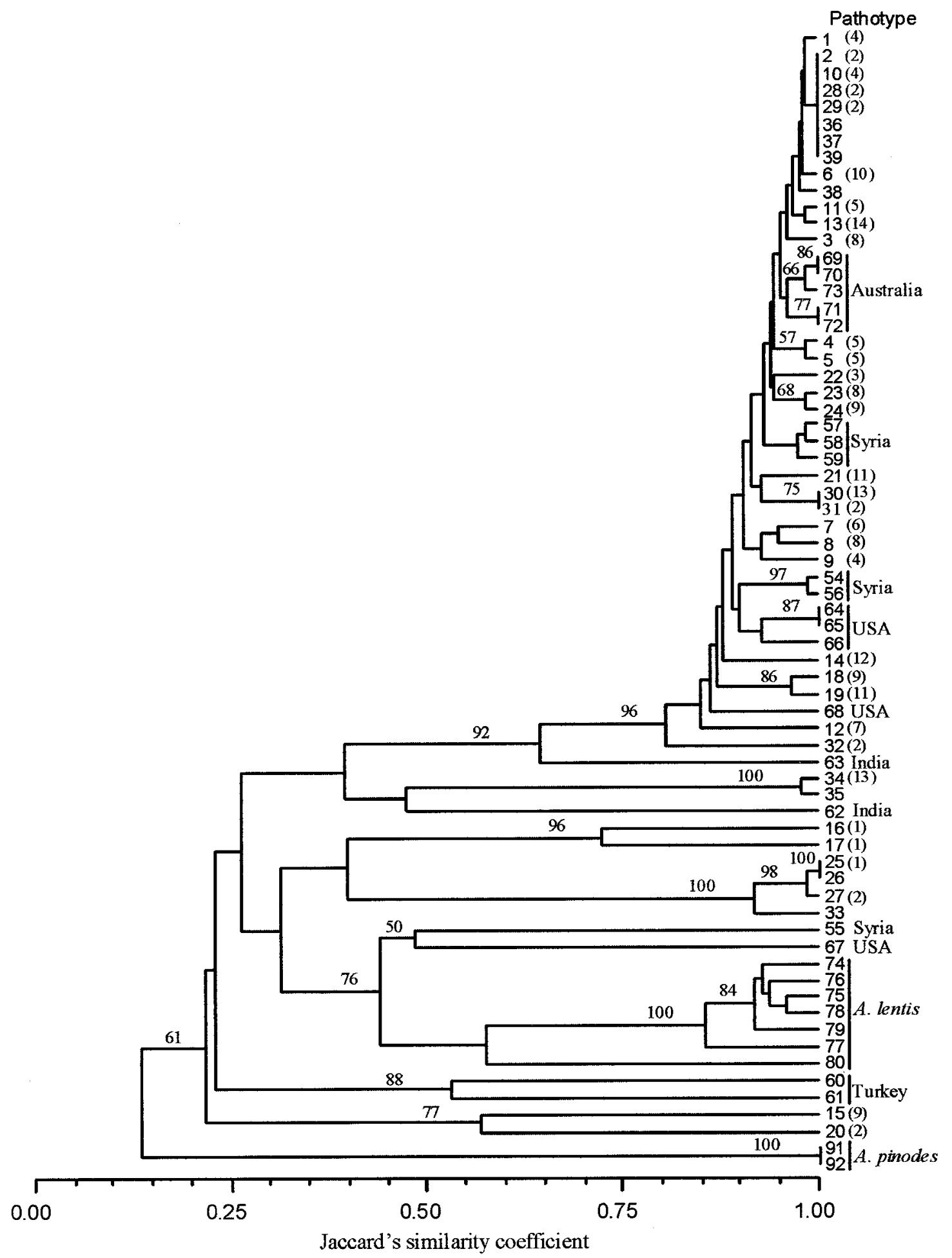

Fig. 3. Dendogram showing diversity of Ascochyta rabiei isolates from Canada in relation to those from other countries and compared with A. lentis and A. pinodes based on random amplified polymorphic DNA banding patterns from eight primers. Numbers on branches indicate percentages from 1,000 bootstrap replicates; only numbers higher than 50 are shown. Numbers in brackets are pathotype groups based on virulence on five kabuli and three desi differential lines. 
cospores, which recently were reported for the first time from Canada (1), further enhances this potential. Faced with a genetically diverse, sexually reproducing pathogen population, plant breeders and pathologists need to work together to develop durable forms of resistance. Also, pathologists need to monitor changes in the pathogen population to anticipate the breakdown of resistance in existing chickpea cultivars.

\section{ACKNOWLEDGMENTS}

We thank R. A. A. Morrall, University of Saskatchewan, Saskatoon, SK; V. Higgins, University of Toronto, Toronto, ON; R. Hannan, United States Department of Agriculture, Pullman, WA; R. Ford, P. Taylor, and T. Phan, University of Melbourne, Australia; and S. D. Singh, International Crops Research Institute for the Semi-Arid Tropics, India for supplying isolates of A. rabiei; and K. Singh of ICRISAT, India, A. Vandenberg of the University of Saskatchewan, Canada, and scientists at ICARDA, Syria for supplying chickpea lines.

\section{LITERATURE CITED}

1. Armstrong, C. L., Chongo, G., Gossen, B. D., and Duczek, L. J. 2001. Mating type distribution and incidence of the teleomorph of Ascochyta rabiei (Didymella rabiei) in Canada. Can. J. Plant Pathol. 23:110-113.

2. Chongo, G., Buchwaldt, L., Anderson, K., and Gossen, B. D. 2000. Saskatchewan chickpea disease survey-1999. Can. Plant. Dis. Surv. 80:86-87.

3. Chongo, G., and Gossen, B. D. 2001. Effect of plant age on resistance to Ascochyta rabiei in chickpea. Can. J. Plant Pathol. 23.358-363.

4. Chongo, G., Gossen, B. D., and Buchwaldt, L. 1999. Fungicidal control of Ascochyta blight in chickpea in 1999. Report No. 99. Pages 275-276 in: 1999 Pesticide Management Research Reports. Agriculture \& Agri-Food Canada, Ottawa, ON, Canada.

5. Fischer, C., Porta-Puglia, A., and Barz, W. 1995. RAPD analysis of pathogenic variability in Ascochyta rabiei. J. Phytopathol. 143:601-607.

6. Helms, D., Panella, L., Buddenhagen, I. W., Workneh, F., Turker, C. L., Foster, K. W., and Gepts, P. L. 1992. Registration of 'UC27' Chickpea. Crop Sci. 32:499-500.
7. Jan, H., and Wiese, M. V. 1991. Virulence forms of Ascochyta rabiei affecting chickpea in the Palouse. Plant Dis. 75:904-906.

8. Kaiser, W. J. 1997. Inter- and intranational spread of Ascochyta pathogens of chickpea, faba bean, and lentil. Can. J. Plant Pathol. 19:215-224.

9. Kaiser, W. J., and Küsmenoglu, I. 1997. Distribution of mating types and the teleomorph of Ascochyta rabiei on chickpea in Turkey. Plant Dis. 81:1284-1287.

10. Kaiser, W. J., Wang, B. C., and Rogers, J. D. 1997. Ascochyta fabae and A. lentis: Host specificity, teleomorphs (Didymella), hybrid analysis, and taxonomic status. Plant Dis. 81:809-816.

11. Khan, M. S. A., Ramsey, M. D., Corbère, A., Infantino, A., Porta-Puglia, A., Bouznad, Z., and Scott, E. S. 1999. Ascochyta blight of chickpea in Australia: Identification, pathogenicity and mating type. Plant Pathol. 48:230-234.

12. Morjane, H., Geistlinger, J., Harrabi, M., Weising, K., and Kahl, G. 1994. Oligonucleotide fingerprinting detects genetic diversity among Ascochyta rabiei isolates from a single chickpea field in Tunisia. Curr. Genet. 26:191-197.

13. Morrall, R. A. A., and McKenzie, D. L. 1974. A note on the inadvertent introduction to North America of Ascochyta rabiei, a destructive pathogen of chickpea. Plant Dis. Rep. 58:34-35.

14. Muehlbauer, F. J., Van Rheenen, H. A., and Kaiser, W. J. 1998. Registration of 'Myles' chickpea. Crop Sci. 38:283.

15. Navas-Cortés, J. A., Pérez-Artés, E., JiménezDíaz, R. M., Llobell, A., Bainbridge, B. W., and Heale, J. B. 1998. Mating type, pathotype and RAPDs analysis in Dydmella rabiei, the agent of Ascochyta blight of chickpea. Phytoparasitica 26:199-212.

16. Navas-Cortés, J. A., Trapero-Casas, A., and Jiménez-Díaz, R. M. 1995. Survival of Didymella rabiei in chickpea straw debris in Spain. Plant Pathol. 44:332-339.

17. Nene, Y. L., and Reddy, M. V. 1987. Chickpea diseases and their control. Pages 233-270 in: The Chickpea. M. C. Saxena and K. B. Singh, eds. CAB International, Oxfordshire, UK.

18. Porta-Puglia, A., Crinò, P., and Mosconi, C. 1996. Variability in virulence to chickpea of an Italian population of Ascochyta rabiei. Plant Dis. 80:39-41.

19. Qureshi, S. H., and Alam, S. S. 1984. Patho- genic behaviour of Ascochyta rabiei isolates on different cultivars of chickpea in Pakistan. Int. Chickpea Newsl. 11:29-31.

20. Reddy, M. V., and Kabbabeh, S. 1985. Pathogenic variability in Ascochyta rabiei (Pass.) Lab. in Syria and Lebanon. Phytopathol. Mediterr. 24:265-266.

21. Reddy, M. V., Singh, K. B., and Malhotra, R. S. 1992. Multi location evaluation of chickpea germplasm and breeding lines for resistance to Ascochyta blight. Phytopathol. Mediterr. 31:59-66.

22. Rohlf, F. J. 1998. NTSYS-pc: Numerical Taxonomy and Multivariate Analysis System. Version 2.0. Applied Biostatistics Inc., New York.

23. Santra, D. K., Singh, G., Kaiser, W. J., Gupta, V. S., Ranjekar, P. K., and Muehlbauer, F. J. 2001. Molecular analysis of Ascochyta rabie (Pass.) Labr., the pathogen of Ascochyta blight in chickpea. Theor. Appl. Genet. 102:676-682.

24. Trapero-Casas, A., and Kaiser, W. J. 1992 Development of Didymella rabiei on chickpea debris. Phytopathology 82:1261-1266.

25. Trapero-Casas, A., Navas-Cortés, J. A., and Jiménez-Diaz, R. M. 1996. Airborne ascospores of Didymella rabiei as a major primary inoculum for Ascochyta blight epidemics in chickpea crops in southern Spain. Eur. J. Plant Pathol. 102:237-245.

26. Udupa, S. M., Weigand, F., Saxena, M. C., and Kahl, G. 1998. Genotyping with RAPD and microsatellite markers resolves pathotype diversity in the Ascochyta blight pathogen of chickpea. Theor. Appl. Genet. 97:299-307.

27. Vir, S., and Grewal, J. S. 1974. Physiologic specialization in Ascochyta rabiei, the causal organism of gram blight. Ind. Phytopathol. 27:355-360.

28. Weising, K., Kaemmer, D., Epplen, J. T., Weigand, F., Saxena, M. C., and Kahl, G. 1991. DNA fingerprinting of Ascochyta rabiei with synthetic oligodeoxynucleotides. Curr. Genet. 19:483489.

29. Wilson, A. D., and Kaiser, W. J. 1995. Cytology and genetics of sexual incompatibility in Didymella rabiei. Mycologia 87:795-804.

30. Yap, I., and Nelson, R. J. 1996. Winboot: A program for performing bootstrap analysis of binary data to determine the confidence limits of UPGMA-based dendogram. IRRI. Res. Pap. Ser. No. 14. International Rice Research Institute, Manila, the Philippines. 


\section{ERRATUM / Volume 88, Number 1}

In the article "Genetic Diversity of Ascochyta rabiei in Canada," by G. Chongo, B. D. Gossen, L. Buchwaldt, T. Adhikari, and S. R. Rimmer, pages 4-10, paragraphs three and four in the Results section and Table 3 should read as follows:

Pathotype 1, which was represented by three Canadian isolates, was not virulent on any line (Tables 2 and 3). Pathotype 2 was virulent only on cv. UC27. It was the most common pathotype collected (eight isolates), and was found in 7 of 25 fields (data not shown). Pathotype 4 (five isolates) was virulent on UC27, ICC 4200, and ICC 4475. Cultivar Sanford, which lost its position as the dominant cultivar in the region in 1999 to 2000 due to declining levels of resistance, was susceptible to pathotypes $5,6,7,9,11,12$, and 13 (16 isolates).

The small-seeded kabuli lines ILC 4421, ILC 3856, and Flip 83-48 exhibited a broader range of resistance than the large-seeded kabuli cvs. Sanford and UC27. None of the isolates were virulent on line ILC 4421, and two were virulent on each of Flip 83-48 and ILC 3856 (Tables 2 and 3). None of the desi lines were susceptible to pathotypes $1,2,9$, and 10 , but all were susceptible to pathotypes 5,7 , and 14 . Lines ICC 4200, ICC 4475, and ICC 6328 were susceptible to 20, 19, and 5 of the isolates, respectively (Tables 2 and 3). Seventeen of 18 isolates from other countries were distributed among the pathotypes differentiated with Canadian isolates (data not shown).

Table 3. Disease reaction and pathotype groupings of 40 isolates of Ascochyta rabiei from Saskatchewan, Canada on five kabuli and three desi chickpea differential lines ${ }^{\mathrm{a}}$

\begin{tabular}{|c|c|c|c|c|c|c|c|c|c|}
\hline \multirow[b]{2}{*}{ Pathotype } & \multirow[b]{2}{*}{ No. ${ }^{b}$} & \multicolumn{8}{|c|}{ Differential line or cultivar } \\
\hline & & $\begin{array}{l}\text { UC } \\
27\end{array}$ & $\begin{array}{c}\text { ICC } \\
4200^{c}\end{array}$ & $\begin{array}{c}\text { ICC } \\
4475^{\mathrm{c}}\end{array}$ & $\begin{array}{l}\text { ICC } \\
\text { 6328 }^{c}\end{array}$ & Sanford & $\begin{array}{l}\text { ILC } \\
3856\end{array}$ & $\begin{array}{l}\text { FLIP } \\
83-48\end{array}$ & $\begin{array}{l}\text { ILC } \\
4421\end{array}$ \\
\hline 1 & 3 & $\mathrm{R}$ & $\mathrm{R}$ & $\mathrm{R}$ & $\mathrm{R}$ & $\mathrm{R}$ & $\mathrm{R}$ & $\mathrm{R}$ & $\mathrm{R}$ \\
\hline 2 & 8 & S & $\mathrm{R}$ & $\mathrm{R}$ & $\mathrm{R}$ & $\mathrm{R}$ & $\mathrm{R}$ & $\mathrm{R}$ & $\mathrm{R}$ \\
\hline 3 & 3 & S & $\mathrm{S}$ & $\mathrm{R}$ & $\mathrm{R}$ & $\mathrm{R}$ & $\mathrm{R}$ & $\mathrm{R}$ & $\mathrm{R}$ \\
\hline 4 & 5 & S & $S$ & $S$ & $\mathrm{R}$ & $\mathrm{R}$ & $\mathrm{R}$ & $\mathrm{R}$ & $\mathrm{R}$ \\
\hline 5 & 3 & S & $\mathrm{S}$ & $S$ & $\mathrm{~S}$ & $S$ & $\mathrm{R}$ & $\mathrm{R}$ & $\mathrm{R}$ \\
\hline 6 & 3 & S & $S$ & S & $\mathrm{R}$ & $S$ & $\mathrm{R}$ & $\mathrm{R}$ & $\mathrm{R}$ \\
\hline 7 & 1 & S & S & $S$ & $\mathrm{~S}$ & S & S & $\mathrm{R}$ & $\mathrm{R}$ \\
\hline 8 & 3 & S & $\mathrm{R}$ & $S$ & $\mathrm{R}$ & $\mathrm{R}$ & $\mathrm{R}$ & $\mathrm{R}$ & $\mathrm{R}$ \\
\hline 9 & 4 & S & $\mathrm{R}$ & $\mathrm{R}$ & $\mathrm{R}$ & S & $\mathrm{R}$ & $\mathrm{R}$ & $\mathrm{R}$ \\
\hline 10 & 1 & $\mathrm{~S}$ & $\mathrm{R}$ & $\mathrm{R}$ & $\mathrm{R}$ & $\mathrm{R}$ & $S$ & $\mathrm{R}$ & $\mathrm{R}$ \\
\hline 11 & 2 & S & $S$ & $\mathrm{R}$ & $\mathrm{R}$ & $S$ & $\mathrm{R}$ & $\mathrm{R}$ & $\mathrm{R}$ \\
\hline 12 & 1 & S & $\mathrm{R}$ & $S$ & $\mathrm{R}$ & $S$ & $\mathrm{R}$ & $\mathrm{R}$ & $\mathrm{R}$ \\
\hline 13 & 2 & S & $S$ & $S$ & $\mathrm{R}$ & $S$ & $\mathrm{R}$ & $S$ & $\mathrm{R}$ \\
\hline 14 & 1 & S & S & S & $\mathrm{S}$ & $\mathrm{R}$ & $\mathrm{R}$ & $\mathrm{R}$ & $\mathrm{R}$ \\
\hline
\end{tabular}

${ }^{\text {a }}$ Based on a 0-to-9 scale where 0 to $3=$ resistant (R) and 4 to $9=$ susceptible (S).

${ }^{\mathrm{b}}$ Number of isolates.

${ }^{\mathrm{c}}$ Desi chickpea line. 